\title{
Reforested soil under drip irrigation with treated wastewater from poultry slaughterhouse
}

\author{
Izabela R. C. Araujoํㅜㄹ Silvio C. Sampaio ${ }^{1}$, Antonio Paz-Gonzalez ${ }^{2}$, Márcio A. Vilas-Boas ${ }^{1}$, \\ Affonso C. Gonçalves Junior ${ }^{3} \&$ Flávio D. Szekut ${ }^{1}$
}

${ }^{1}$ Universidade Estadual do Oeste do Paraná. Cascavel, PR, Brasil. E-mail: izabelarcaraujo@gmail.com (Corresponding author) - ORCID: 0000-0002-6279-6521; silvio.sampaio@unioeste.br - ORCID: 0000-0002-9034-432X; james_morais@hotmail.com - ORCID: 0000-0002-0770-0320; marcio.vilasboas@unioeste.br ORCID: 0000-0003-3444-8164; flaviodanielszekut@gmail.com - ORCID: 0000-0003-1028-9074

${ }^{2}$ Universidade da Coruña/Centre for Advanced Scientific Research. A Coruña, Espanha. E-mail: tucho@udc.es - ORCID: 0000-0001-6318-8117

${ }^{3}$ Universidade Estadual do Oeste do Paraná. Marechal Cândido Rondon, PR, Brasil. E-mail: affonso133@hotmail.com - ORCID: 0000-0002-1699-1545

\begin{abstract}
The disposal of treated effluents on soil is the main final use of wastewater in Brazil. Although this practice can promote improvements of some soil attributes, there is a need for monitoring in order to ensure that potential environmental impacts are not harmful. Thus, the purpose of this study was to evaluate the effects of treated effluent from a poultry slaughterhouse on the chemical attributes of an Oxisols, in Matelândia-PR, Brazil under drip irrigation. The soil attributes $\mathrm{P}, \mathrm{K}, \mathrm{Fe}, \mathrm{Cu}, \mathrm{Zn}, \mathrm{Mn}, \mathrm{pH}$ in $\mathrm{CaCl}_{2}, \mathrm{H}+\mathrm{Al}, \mathrm{Al}$, $\mathrm{Ca}, \mathrm{Mg}$, cation exchange capacity (CEC), and percent base saturation (V) were evaluated under four effluent application rates, $0,100,200$ and $300 \mathrm{~m}^{3} \mathrm{ha}^{-1} \mathrm{~d}^{-1}$ with treated effluents on three successive sampling dates. As main results it was observed that high irrigation rates increased soil phosphorus and potassium concentrations. In addition, an association between the increase of soil potential acidity and exchangeable acidity was detected, although $\mathrm{pH}$ did not vary significantly either between treatments or between sampling dates.
\end{abstract}

Key words: forestry production, Eucalyptus, Oxisols

\section{Solo reflorestado sob irrigação por gotejamento com efluentes tratados de abatedouro de aves}

RESUMO: A disposição de efluentes tratados sobre o solo pode ser considerada o principal destino final de águas residuárias no Brasil. Embora possa promover melhorias em relação a alguns atributos do solo, esta prática precisa ser monitorada para garantir que os impactos ambientais não sejam negativos. Assim, objetivou-se com este trabalho avaliar os efeitos da disposição, por gotejamento, do efluente tratado de um abatedouro de aves sobre os atributos químicos de um Latossolo, em Matelândia, PR. Os atributos do solo: $\mathrm{P}, \mathrm{K}, \mathrm{Fe}, \mathrm{Cu}, \mathrm{Zn}, \mathrm{Mn}, \mathrm{pH}$ em $\mathrm{CaCl}_{2}, \mathrm{H}+\mathrm{Al}, \mathrm{Al}, \mathrm{Ca}, \mathrm{Mg}$, capacidade de troca catiônica (CTC), saturação por bases foram avaliados sob quatro taxas de irrigação, $0,100,200$ e $300 \mathrm{~m}^{3} \mathrm{ha}^{-1} \mathrm{~d}^{-1}$, com efluentes tratados em três datas sucessivas de amostragem. Como principais resultados observou-se que as altas taxas de aplicação do efluente praticadas, influenciaram no incremento das concentrações de fósforo e potássio no solo. Além disso, pôde-se observar uma relação entre o aumento da acidez potencial e acidez trocável, mesmo que o pH não tenha variado tanto nem entre os tratamentos nem entre as ocasiões de coletas de dados.

Palavras-chave: produção florestal, Eucalyptus, Latossolo 


\section{INTRODUCTION}

With a production exceeding 13 million tons in 2017, Brazil has been now becoming the second main producer of poultry in the world, standing only behind the United States of America, with a production of approximately 19 million tons (USDA, 2018).

This prominent position in the world market implies concerns about the sustainability of the business, especially regarding water consumption and wastewater disposal. The main post-treatment disposal alternative of this effluent in Brazil is the application into the soil. This practice may also be contemplated as a secondary treatment (Bustillo-Lecompte \& Mehrvar, 2015). However, considering the high disposal rates practiced by the slaughterhouses, especially in reforested areas, the need for research about the effects of this effluent on soil becomes evident. Several studies about wastewater effects on soil properties under forest (Guo \& Sims, 2000, 2003; Tzanakakis et al., 2011; Mendes et al., 2013; Maroneze et al., 2014; Fernandes et al., 2015; Minhas et al., 2015) and even on irrigated forest systems (Hermes et al., 2015; Morais, 2017) have been performed until now. However, further research is needed to assess the most appropriate rates of effluent application and the effects of commonly employed rates on soil attributes.

Thus, the aim of this study was to investigate the effects of the disposal of treated effluents from poultry slaughterhouse on the chemical attributes of a reforested soil.

\section{Material ANd Methods}

The experiment was carried out in reforestation areas of an industrial poultry slaughtering unit (IPSU), in the municipality of Matelândia, Paraná state, Brazil, at latitude $25^{\circ} 12.1577^{\prime} \mathrm{S}$ and longitude $53^{\circ} 57.1925^{\prime} \mathrm{W}$.

The IPSU slaughters and processes 340,000 chickens $\mathrm{d}^{-1}$. A current production of approximately $7,500 \mathrm{~m}^{3}$ of effluent $\mathrm{d}^{-1}$ is generated, resulting from about $23 \mathrm{~L}$ of effluent chicken ${ }^{-1}$. These effluents are treated in three stages: a) preliminary treatment, with separation of gross solids; b) primary treatment with removal of suspended solids and c) oils and fat removal by a dissolved air flotation machine and biological treatment in an aerated reactor with secondary decanters, which constitute the activated sludge system. The treated effluent is disposed in the reforestation areas of IPSU.

Every week the physico-chemical characteristics of this effluent were analysed. Table 1 shows the mean values of the variables monitored during the experimental period reported here. Besides that, the amounts of $\mathrm{Sn}, \mathrm{Zn}, \mathrm{Pb}, \mathrm{Cd}, \mathrm{Cu}, \mathrm{Fe}, \mathrm{Mn}, \mathrm{Ag}$, $\mathrm{Hg}, \mathrm{Cr}, \mathrm{K}, \mathrm{Ni}$, Se and Co were determined by Atomic Absorption
Spectroscopy, method 3111A, described by APHA (1995). The concentrations of these elements in the effluent were below the limit of detection. The $\mathrm{pH}$, chemical oxygen demand (COD), biochemical oxygen demand (BOD), Kjeldahl total nitrogen (KTN), total suspended solids, electrical conductivity, total phosphorus and oils and greases were determined, respectively by the methods: Potentiometric $-4500-\mathrm{H}^{+}$, Colorimetric-5220 D, Titulometric - 4500 N, Gravimetric 2540D, Condutivimetric - 2510B, Hexane Extractable Gravimetric Method - 5520B, described by APHA (1995)

Sixteen experimental plots were established, with an average area of $296.8 \mathrm{~m}^{2}$ within a field of approximately 98 ha, planted with clonal seedlings of Eucalyptus urophylla, on Oxisols. Four treatments were applied to these plots in a completely randomized design, with irrigation rates of 0 , 100, 200 and $300 \mathrm{~m}^{3} \mathrm{ha}^{-1} \mathrm{~d}^{-1}$ with treated effluent and four repetitions. The rate of $100 \mathrm{~m}^{3} \mathrm{ha}^{-1} \mathrm{~d}^{-1}$ was approved by the responsible environmental agency, for application of this effluent at the study site, and defined based on an infiltration test using the concentric ring method. The rates of 200 and $300 \mathrm{~m}^{3} \mathrm{ha}^{-1} \mathrm{~d}^{-1}$ were defined based on industrial demands, projected for the next years.

The irrigated plots were monitored daily for water flow and pressure, using individual flow meters and manometers for each one of them. Thus, the drip irrigation system was installed with individual controllers in each plot. The details of the irrigation system have been described by Morais (2017).

Soil samples were collected at the 0 to $0.20 \mathrm{~m}$ depth, on three moments: before beginning of irrigation, and then after 6 and 15 months with irrigation. On each date, five samples were collected per plot, and each sample was composed of six subsamples. In each sample, the following attributes were evaluated: $\mathrm{P}, \mathrm{K}, \mathrm{Fe}, \mathrm{Cu}, \mathrm{Zn}, \mathrm{Mn}$ (extracted by Mehlich solution), $\mathrm{pH}$ in $\mathrm{CaCl}_{2}, \mathrm{H}+\mathrm{Al}$ ( $\mathrm{pH} 7.5$ ), $\mathrm{Al}, \mathrm{Ca}, \mathrm{Mg}$ (extracted by $1 \mathrm{M} \mathrm{KCl}$ ) cation exchange capacity (CEC), and percent base saturation (V), as well as the micronutrients $\mathrm{Fe}, \mathrm{Mn}, \mathrm{Zn}$ and $\mathrm{Cu}$, according to the methodology described by EMBRAPA (1997).

The differences between samples of the treatments studied and the successive collection moments were compared by Tukey tests at $\mathrm{p} \leq 0.05$ significance level. In addition, adjustment of exponential equations relating the soil attributes and irrigation rates.

\section{Results ANd Discussion}

None of the studied soil attributes had significant differences between treatments, at 0.05 significance level, using the Tukey test, neither at 6 nor at 15 months after irrigation,

Table 1. Mean values and standard deviation of selected physico-chemical variables of the industrial poultry slaughtering unit (IPSU) treated effluent, as well as the respective rates applied by each treatment

\begin{tabular}{|c|c|c|c|c|}
\hline \multirow{2}{*}{ Variable } & \multirow{2}{*}{$\begin{array}{c}\text { Mean and } \\
\text { Standard deviation }\end{array}$} & \multicolumn{3}{|c|}{ Application rates $\left(\mathrm{m}^{3} \mathrm{ha}^{-1} \mathrm{~d}^{-1}\right)$} \\
\hline & & 100 & 200 & 300 \\
\hline $\mathrm{pH}$ & $7.0 \pm 0.1$ & - & - & - \\
\hline Electrical conductivity & $0.9 \pm 0.06\left(\mathrm{dS} \mathrm{cm}^{-1}\right)$ & - & - & - \\
\hline Total suspended solids (TSS) & $72.1 \pm 11.6\left(\mathrm{mg} \mathrm{L}^{-1}\right)$ & 7.21 & 14.42 & 21.63 \\
\hline Kjeldahl total nitrogen (KTN) & $48.7 \pm 11.5\left(\mathrm{mg} \mathrm{L}^{-1}\right)$ & 4.87 & 9.74 & 14.61 \\
\hline Total Phosphorus & $20.2 \pm 5.5\left(\mathrm{mg} \mathrm{L}^{-1}\right)$ & 2.02 & 4.05 & 6.08 \\
\hline Biochemical oxygen demand (BOD) & $32.9 \pm 10.4\left(\mathrm{mg} \mathrm{L}^{-1}\right)$ & 3.29 & 6.58 & 9.88 \\
\hline Chemical oxygen demand (COD) & $80.9 \pm 14.7\left(\mathrm{mg} \mathrm{L}^{-1}\right)$ & 8.09 & 16.19 & 24.28 \\
\hline Oil and fats & $6.3 \pm 1.9\left(\mathrm{mg} \mathrm{L}^{-1}\right)$ & 0.63 & 1.26 & 1.89 \\
\hline
\end{tabular}


when compared to the data obtained in the pre-irrigation test. However, these results allowed verifying the temporal evolution of the attributes studied, as well as the effect of irrigation rates.

Forest soils irrigated with treated effluents at high rates, as it is the case in this work, were expected to show evident differences between treatments in the short term. This was not always the case as shown in Figure 1, where it can be observed that several soil attributes, but not all of them, showed a trend as a function of the imposed effluent application rates.

In the case of $\mathrm{P}$ (Figure 1A) a clear trend towards increasing accumulation with increasing irrigation dose can be observed at 15 months of irrigation. This is due to the fact that $\mathrm{P}$ is a stable nutrient with low solubility, and it tends to accumulate in the soil surface, even when its source is wastewater, with low concentrations. Therefore, the use of these effluents for irrigation can be valuable to plants, with low environmental risk, even if applied continuously for long terms (Degens et al., 2000).

After 15 months of irrigation, the phosphorus contents in the soil samples were 4.3, 13.2, 21.8 and $34.7 \mathrm{~kg}$ of $\mathrm{P} \mathrm{ha}{ }^{-1}$, for treatments $\mathrm{T} 0, \mathrm{~T} 1, \mathrm{~T} 2$ and $\mathrm{T} 3$, respectively, showing an increasing trend in the concentration of this nutrient with increasing effluent application rates. If the nutritional requirements of the genus Eucalyptus are considered, whose average value is around $44 \mathrm{~kg} \mathrm{P} \mathrm{ha}^{-1}$ (Silveira \& Gava, 2014), it brings about that the application of the effluent at $\mathrm{T} 3$ rate could be advantageous for maintenance of the phosphorus stock in the soil, even with a surplus after harvesting.

Except for the control treatment T0, without effluent, a significant increase in the soil phosphorus stock was observed from the beginning of the experiment until six months under irrigation, but this was followed by a decrease in these stocks between the $6^{\text {th }}$ and $15^{\text {th }}$ months under irrigation (Figure 1A). This behavior can be explained by the high nutritional requirements of eucalyptus at this particular vegetative stage, which reach their apex between 12 and 24 months, when the treetop closure happens (Laclau et al., 2010).

Soil pH (Figure 1C) decreased in the four treatments, as well as potential acidity (Figure 1D), although the reduction was rather small (Table 2). This fact may be associated with an increase in exchangeable $\mathrm{Al}^{3+}$ (Figure 1E), which is explained by the fact
A.

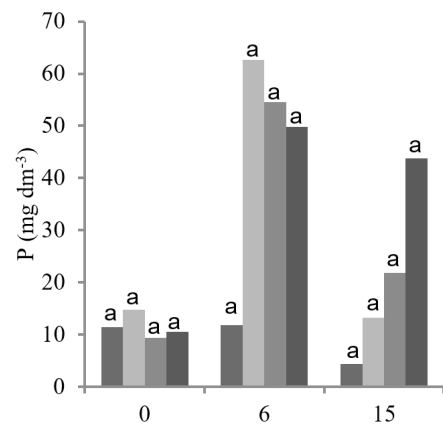

E.

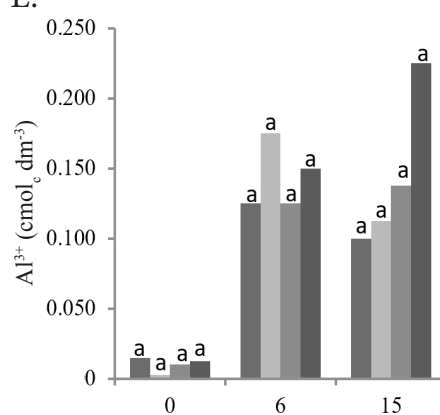

I.

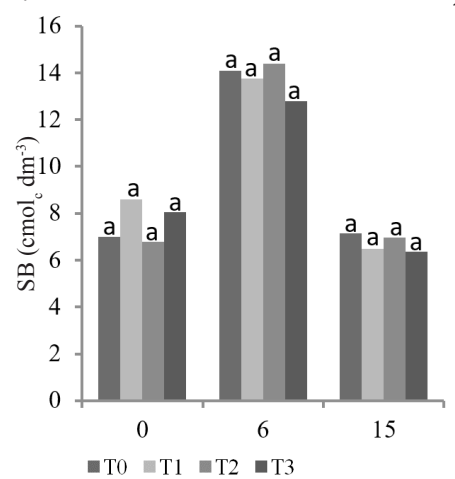

B.

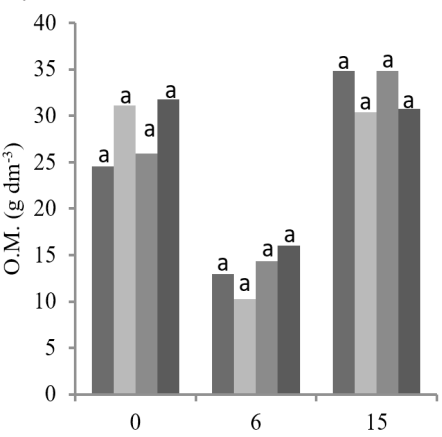

F.

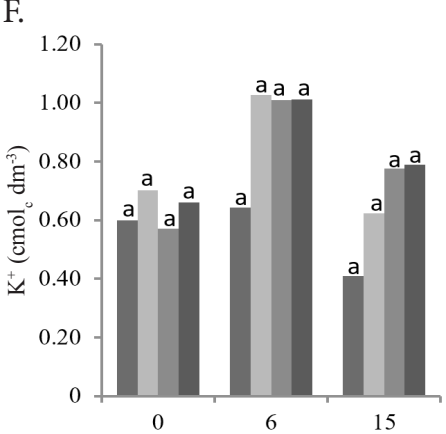

J.

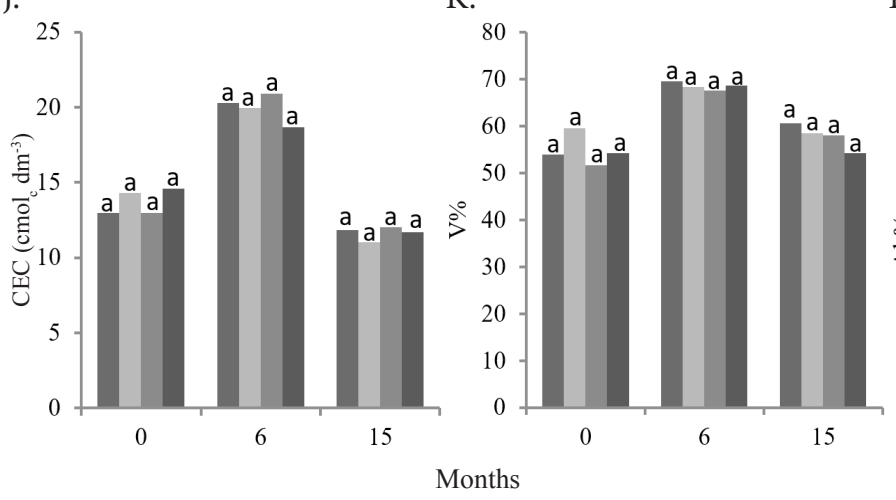

C.

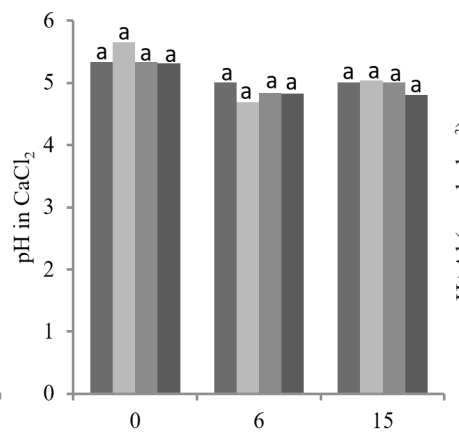

G.

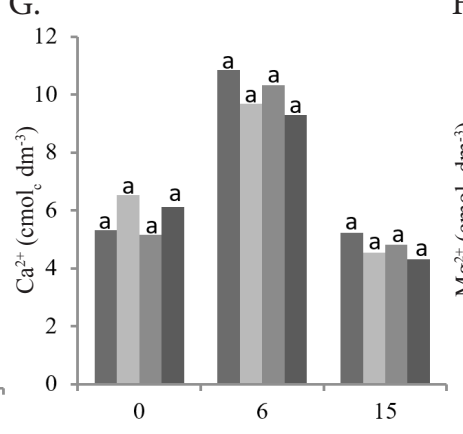

K.
D.

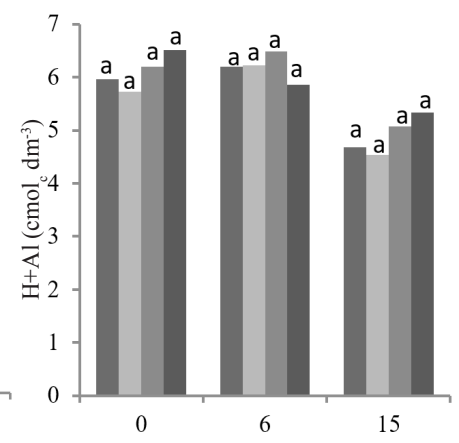

H.

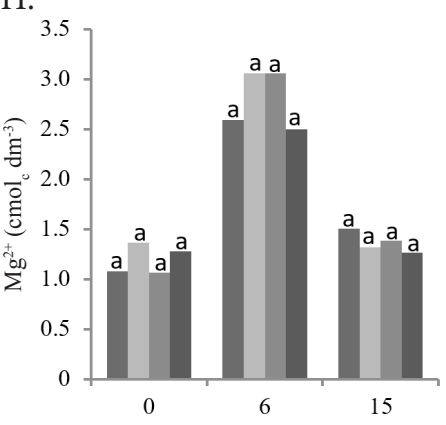

L.

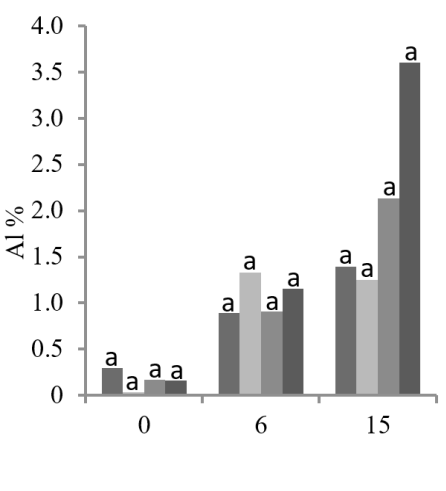

There is no significant difference among the means by Tukey test at $\mathrm{p} \leq 0.05$

Figure 1. Temporal evolution of forest soil attributes: (A) $\mathrm{P},(\mathrm{B})$ Organic matter, (C) $\mathrm{pH}$ in $\mathrm{CaCl}_{2}$, (D) $\mathrm{H}+\mathrm{Al}$, (E) $\mathrm{Al}^{3+}$, (F) $\mathrm{K}^{+}$, (G) $\mathrm{Ca}^{2+},(\mathrm{H}) \mathrm{Mg}^{2+}$, (I) Sum of bases (SB), (J) Cation exchange capacity (CEC), (K) Base saturation (V) and (L) Al\%, in plots submitted to 0 (T0), 100 (T1), 200 (T2), 300 (T3) $\mathrm{m}^{3} \mathrm{ha}^{-1} \mathrm{~d}^{-1}$, before beginning of irrigation and after six and 15 months of irrigation 
Table 2. Changes of chemical soil attributes from samples collected before and after 15 months of irrigation with treated effluent from poultry slaughterhouse

\begin{tabular}{|c|c|c|c|c|c|}
\hline Variable & Treatment & $\begin{array}{c}\text { Mean } \\
\text { pre-irrigation }\end{array}$ & $\begin{array}{c}\text { Mean } \\
15^{\text {th }} \text { irrigation month }\end{array}$ & $\begin{array}{c}\text { Mean } \\
\text { variation }\end{array}$ & $\begin{array}{c}\text { Mean } \\
\text { variation \%b }\end{array}$ \\
\hline \multirow{4}{*}{$P\left(m g d^{-3}\right)$} & TO & $11.4 \pm 13.7$ & $4.3 \pm 2.4$ & -7.1 & $-62 \%$ \\
\hline & T1 & $14.7 \pm 13.8$ & $13.2 \pm 13.1$ & -1.6 & $-11 \%$ \\
\hline & T2 & $9.3 \pm 8.9$ & $21.8 \pm 15.1$ & 12.5 & $134 \%$ \\
\hline & T3 & $10.6 \pm 8.6$ & $34.7 \pm 32.7$ & 33.1 & $314 \%$ \\
\hline \multirow{4}{*}{ Organic matter $\left(\mathrm{g} \mathrm{dm}^{-3}\right)$} & TO & $24.5 \pm 5.5$ & $34.9 \pm 8.2$ & 10.3 & $42 \%$ \\
\hline & T1 & $31.1 \pm 5.8$ & $30.4 \pm 6.4$ & -0.7 & $-2 \%$ \\
\hline & T2 & $25.9 \pm 7.3$ & $34.9 \pm 9.0$ & 9.0 & $35 \%$ \\
\hline & T3 & $31.8 \pm 7.0$ & $30.8 \pm 5.1$ & -1.0 & $-3 \%$ \\
\hline \multirow{4}{*}{$\mathrm{pH}$ in $\mathrm{CaCl}_{2}$} & TO & $5.3 \pm 0.4$ & $5.0 \pm 0.1$ & -0.3 & - \\
\hline & T1 & $5.6 \pm 0.4$ & $5.0 \pm 0.2$ & -0.6 & - \\
\hline & T2 & $5.3 \pm 0.4$ & $5.0 \pm 0.3$ & -0.3 & - \\
\hline & T3 & $5.3 \pm 0.4$ & $4.8 \pm 0.1$ & -0.5 & - \\
\hline \multirow{4}{*}{$\mathrm{H}+\mathrm{AL}\left(\mathrm{cmol}_{\mathrm{c}} \mathrm{dm}^{-3}\right)$} & TO & $6.0 \pm 1.7$ & $4.7 \pm 0.9$ & -1.3 & $-22 \%$ \\
\hline & T1 & $5.7 \pm 1.6$ & $4.5 \pm 0.5$ & -1.2 & $-21 \%$ \\
\hline & T2 & $6.2 \pm 1.5$ & $5.1 \pm 1.3$ & -1.1 & $-18 \%$ \\
\hline & T3 & $6.5 \pm 1.2$ & $5.3 \pm 0.5$ & -1.2 & $-18 \%$ \\
\hline \multirow{4}{*}{$\mathrm{Al}^{\beta+}\left(\mathrm{cmol}_{\mathrm{c}} \mathrm{dm}^{-3}\right)$} & TO & $0.015 \pm 0.04$ & $0.10 \pm 0.04$ & 0.1 & $567 \%$ \\
\hline & $\mathrm{T} 1$ & $0.003 \pm 0.01$ & $0.11 \pm 0.08$ & 0.1 & $4400 \%$ \\
\hline & T2 & $0.010 \pm 0.03$ & $0.14 \pm 0.18$ & 0.1 & $1275 \%$ \\
\hline & T3 & $0.013 \pm 0.04$ & $0.23 \pm 0.16$ & 0.2 & $1700 \%$ \\
\hline \multirow{4}{*}{$\mathrm{K}^{+}\left(\mathrm{cmol}_{\mathrm{C}} \mathrm{dm}^{-3}\right)$} & TO & $0.60 \pm 0.21$ & $0.41 \pm 0.09$ & -0.2 & $-31 \%$ \\
\hline & T1 & $0.70 \pm 0.22$ & $0.62 \pm 0.17$ & -0.1 & $-11 \%$ \\
\hline & T2 & $0.57 \pm 0.19$ & $0.78 \pm 0.27$ & 0.2 & $36 \%$ \\
\hline & T3 & $0.66 \pm 0.23$ & $0.79 \pm 0.33$ & 0.1 & $20 \%$ \\
\hline \multirow{4}{*}{$\mathrm{Ca}^{2+}\left(\mathrm{cmol}_{\mathrm{c}} \mathrm{dm}^{-3}\right)$} & TO & $5.3 \pm 1.4$ & $5.2 \pm 0.6$ & -0.1 & $-2 \%$ \\
\hline & T1 & $6.5 \pm 1.8$ & $4.5 \pm 0.9$ & -2.0 & $-31 \%$ \\
\hline & T2 & $5.1 \pm 1.3$ & $4.8 \pm 1.0$ & -0.3 & $-7 \%$ \\
\hline & T3 & $6.1 \pm 2.1$ & $4.3 \pm 0.6$ & -1.8 & $-30 \%$ \\
\hline \multirow{4}{*}{$\mathrm{Mg}^{2+}\left(\mathrm{cmol}_{\mathrm{c}} \mathrm{dm}^{-3}\right)$} & TO & $1.1 \pm 0.39$ & $1.5 \pm 0.3$ & 0.4 & $39 \%$ \\
\hline & T1 & $1.4 \pm 0.34$ & $1.3 \pm 0.3$ & 0.0 & $-3 \%$ \\
\hline & T2 & $1.1 \pm 0.33$ & $1.4 \pm 0.2$ & 0.3 & $31 \%$ \\
\hline & T3 & $1.3 \pm 0.42$ & $1.3 \pm 0.3$ & 0.0 & $-1 \%$ \\
\hline \multirow{4}{*}{$\mathrm{SB}\left(\mathrm{cmol}_{\mathrm{c}} \mathrm{dm}^{-3}\right)$} & TO & $7.0 \pm 1.8$ & $7.1 \pm 0.9$ & 0.1 & $2 \%$ \\
\hline & T1 & $8.6 \pm 2.2$ & $6.5 \pm 1.3$ & -2.1 & $-25 \%$ \\
\hline & T2 & $6.8 \pm 1.6$ & $7.0 \pm 1.2$ & 0.2 & $3 \%$ \\
\hline & T3 & $8.1 \pm 2.6$ & $6.4 \pm 1.0$ & -1.7 & $-21 \%$ \\
\hline \multirow{4}{*}{ CEC $\left(\mathrm{cmol}_{\mathrm{c}} \mathrm{dm}^{-3}\right)$} & TO & $13.0 \pm 2.2$ & $11.8 \pm 1.8$ & -1.2 & $-9 \%$ \\
\hline & $\mathrm{T} 1$ & $14.3 \pm 1.5$ & $11.0 \pm 1.6$ & -3.3 & $-23 \%$ \\
\hline & T2 & $13.0 \pm 1.7$ & $12.0 \pm 1.0$ & -0.9 & $-7 \%$ \\
\hline & T3 & $14.6 \pm 2.3$ & $11.7 \pm 1.3$ & -2.9 & $-20 \%$ \\
\hline \multirow{4}{*}{ V (\%) } & TO & $54.0 \pm 10.9$ & $60.6 \pm 1.9$ & 6.6 & $12 \%$ \\
\hline & T1 & $59.5 \pm 11.6$ & $58.5 \pm 3.9$ & -1.1 & $-2 \%$ \\
\hline & T2 & $51.7 \pm 8.8$ & $58.0 \pm 8.9$ & 6.4 & $12 \%$ \\
\hline & T3 & $54.3 \pm 9.8$ & $54.2 \pm 2.8$ & 0.0 & $0 \%$ \\
\hline
\end{tabular}

${ }^{\text {a }}$ Mean variation in comparison between sample means of pre-irrigation analysis, and post $15^{\text {th }}$ irrigation month irrigations

${ }^{\mathrm{b}}$ Mean percentage variation between sample means of pre-irrigation analysis, and post $15^{\text {th }}$ irrigation month; $\mathrm{T} 0=0 ; \mathrm{T} 1=100 ; \mathrm{T} 2=200 ; \mathrm{T} 3=300 \mathrm{~m}^{3} \mathrm{ha}^{-1} \mathrm{~d}^{-1}$

that phosphorus from wastewater is usually partially bound to organic components and therefore cannot form complexes with Fe or Al ions (Jiménez-Cisneros, 1995). Guo \& Sims (2000, 2003) observed similar results regarding $\mathrm{pH}$ behavior in areas irrigated with slaughterhouse effluent. The authors associated the reduction of $\mathrm{pH}$ with the production of acids associated to nitrification, and the produced organic acids increased the decomposition of forest litter and biological activity.

The organic matter (Figure 1B) contents of T1 and T3 treatments (Table 2 ) showed a low variation after 15 months of irrigation. However, for T0 and T2 treatments there were increases of 42 and 35\%, respectively. Therefore, effluent application may or may not be associated to increasing organic matter contents. The incorporation of organic matter may be more closely related to higher litter production than to irrigation, as organic matter increases are due to the availability of water and nutrients (Guo \& Sims, 2000).
Concentrations of K (Figure 1F) increased by 36 and $20 \%$ for treatments T2 and T3 (Table 2), respectively, whereas, in the other two treatments, a reduction in concentrations was observed. It can be assumed that these reductions in soil $\mathrm{K}$ concentrations in the control treatment (T0) and in the treatment with a lower effluent application rate (T1) are directly linked to nutrient uptake by trees, since $\mathrm{K}$ is one of the elements that most accumulated in Eucalyptus, although it is also wellknown that the maximum consumption of this element occurs between 24 and 36 months after planting (Bellote \& Ferreira, 1993; Bassaco et al., 2018).

The higher levels of soil K observed in treatments T2 and T3 can be a good indicator of the effects of effluent disposal, considering that this nutrient can improve water relations in the leaves, control of stomatal movements and leaf gas exchanges, enhancing transpiration in areas with greater amount of available water (Battie-Laclau et al., 2016). 
These results did not allow identifying patterns in the relationships between irrigation rates and soil contents (Figure 1) for exchangeable Ca (Figure 1G), Mg (Figure 1H), as well as for CEC (Figure 1J) and SB (Figure 1I), although the differences in the values of these attributes show similar trends for a given treatment. In the case of percent base saturation (Figure $1 \mathrm{~K}$ ), it is possible to identify, after 15 months of effluent disposal, a negative interrelationship with the effluent application rates, so that the higher the rate, the lower the percent saturation values; this is clearly related to increasing values of exchangeable $\mathrm{Al}$ (Figure 1L) with increasing irrigation doses (Table 3). Aluminum is one of the main factors inhibiting plant growth in acid soils. If the $\mathrm{pH}$ decreases below 5.0, $\mathrm{Al}$ is solubilized in phytotoxic form mainly as the free $\mathrm{Al}^{3+}$ ion, which can cause inhibition of root growth in Eucalyptus spp. and callus formation at its tips (Kinraide, 1991; Kochian, 1995; Tahara et al., 2005).

The concentrations of $\mathrm{Cu}$ (Figure 2A), Fe (Figure 2B), Mn (Figure 2C) and $\mathrm{Zn}$ (Figure 2D) decreased over the 15-month time interval studied (Table 3 ), both in the irrigated plots and in the control treatment, T0. Therefore, this reduction in soil micronutrients content is not directly related to effluent application, but it is associated either with the consumption or with displacement to the subsurface layers of the soil (Li \& Shuman, 1996; El-Nahhal et al., 2013).

Another possibility could be the adsorption of metals onto manganese oxides, which have negatively charged surfaces at acidic pH, strongly adsorbing the metals (Stahl \& James, 1991). $\mathrm{Cu}$ and $\mathrm{Zn}$ deficiencies are more frequent in clayey and reddish soils rich in Fe and Mn hydroxides and organic matter, which control the availability of these micronutrients in solution (Nascimento et al., 2002).
A.

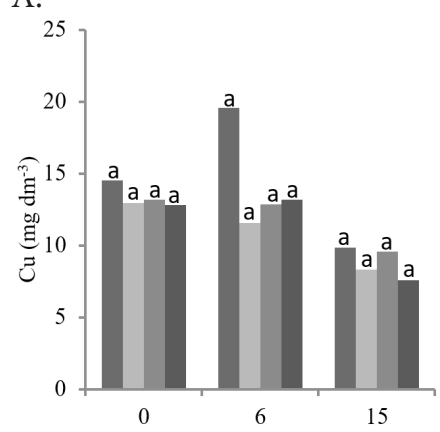

C.

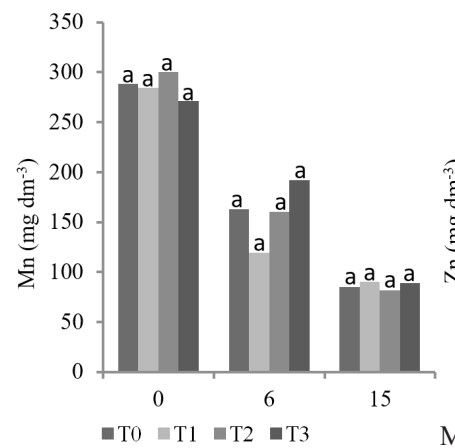

B.

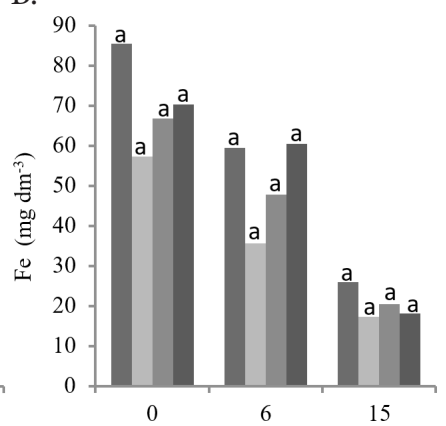

D.

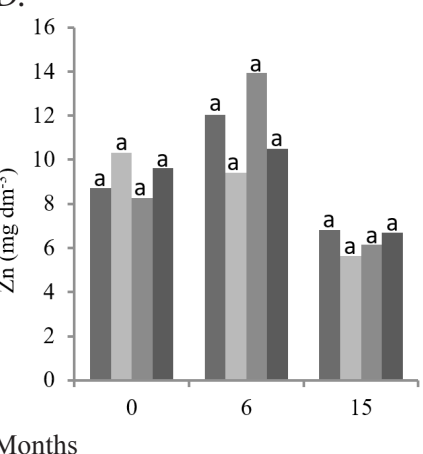

Figure 2. Temporal evolution of forest soil attributes: $\mathrm{Cu}(\mathrm{A}), \mathrm{Fe}$ (B), $\mathrm{Mn}(\mathrm{C})$ and $\mathrm{Zn}$ (D) for forest soil submitted to 0 (T0), 100 (T1), 200 (T2) and 300 (T3) $\mathrm{m}^{3} \mathrm{ha}^{-1} \mathrm{~d}^{-1}$ effluent application rates, before beginning of irrigation and after six and 15 months of irrigation
Table 3. Results of micronutrient and total aluminum analyses of soil samples collected after 15 months of irrigation with treated effluent from poultry slaughterhouse

\begin{tabular}{|c|c|c|c|c|}
\hline $\begin{array}{l}\text { Variable } \\
\left(\mathrm{mg} \mathrm{dm}^{-3}\right)\end{array}$ & Treatment & $\begin{array}{c}\text { Mean } \\
15^{\text {th }} \text { irrigation month }\end{array}$ & $\begin{array}{c}\text { Mean } \\
\text { variation }\end{array}$ & $\begin{array}{c}\text { Mean } \\
\text { variation }\end{array}$ \\
\hline \multirow{4}{*}{$\mathrm{Cu}$} & T0 & 14.5 & 9.8 & $-32 \%$ \\
\hline & T1 & 12.9 & 8.3 & $-36 \%$ \\
\hline & T2 & 13.2 & 9.6 & $-27 \%$ \\
\hline & T3 & 12.8 & 7.6 & $-41 \%$ \\
\hline \multirow{4}{*}{$\mathrm{Zn}$} & TO & 8.7 & 6.8 & $-22 \%$ \\
\hline & $\mathrm{T} 1$ & 10.3 & 5.6 & $-45 \%$ \\
\hline & T2 & 8.3 & 6.2 & $-25 \%$ \\
\hline & T3 & 9.6 & 6.7 & $-30 \%$ \\
\hline \multirow{4}{*}{$\mathrm{Mn}$} & T0 & 288.2 & 85.4 & $-70 \%$ \\
\hline & $\mathrm{T} 1$ & 284.7 & 90.4 & $-68 \%$ \\
\hline & $\mathrm{T} 2$ & 300.4 & 81.8 & $-73 \%$ \\
\hline & T3 & 271.4 & 89.0 & $-67 \%$ \\
\hline \multirow{4}{*}{$\mathrm{Fe}$} & T0 & 85.5 & 26.0 & $-70 \%$ \\
\hline & T1 & 57.4 & 17.3 & $-70 \%$ \\
\hline & $\mathrm{T} 2$ & 66.8 & 20.5 & $-69 \%$ \\
\hline & T3 & 70.4 & 18.1 & $-74 \%$ \\
\hline
\end{tabular}

${ }^{a}$ Mean variation in comparison to the sample means of pre-irrigation analysis

${ }^{\mathrm{b}}$ Mean percentage variation over pre-irrigation sample means; $\mathrm{T} 0=0$; $\mathrm{T} 1=100 ; \mathrm{T} 2=$ 200; T3 $=300 \mathrm{~m}^{3} \mathrm{ha}^{-1} \mathrm{~d}^{-1}$

Exponential equations were adjusted to describe the relationship between the concentrations of selected soil attributes and effluent application rates. Table 4 shows the results of these exponential regressions for soil attributes with determination coefficients $\left(\mathrm{R}^{2}\right)$ higher than 0.7 .

Although, there was no significant difference between the treatments, at 0.05 of significance in the Tukey test, after 15 months of irrigation, when compared to the data obtained in the pre-irrigation evaluation, it was observed a distancing of the treatment means, corresponding with treatments applied rates. This can be verified by the correlations obtained between the irrigation rates and the soil attributes presented in Table 4 . The positive exponential relation to phosphorus in the soil is probably associated with its cumulative effect on the soil, since it is one of the components present in the effluent and presents low mobility in the soil. In relation to the acidity (potential, exchangeable acidity and $\mathrm{Al} \%$ ) that presented high positive correlations with effluent application rates and base saturation, with negative exponential relation, are associated to the organic acids produced as a function of litter decomposition, and consequently, with the competition of $\mathrm{H}^{+}$and $\mathrm{Al}^{3+}$ by active sites with $\mathrm{Ca}^{2+}, \mathrm{Mg}^{2+}$ and $\mathrm{K}^{+}$(Malavolta et al., 1997; Guo \& Sims, 2003).

Table 4. Exponential equations adjusted for selected soil attributes studied as a function of effluent application rate with treated effluent from poultry slaughterhouse, at 15 months of drip irrigation

\begin{tabular}{lcc}
\hline \multicolumn{1}{c}{ Soil attribute } & Equation & $\mathbf{R}^{\mathbf{2}}$ \\
$\mathrm{P}\left(\mathrm{mg} \mathrm{dm}^{-3}\right)$ & $2.3807 \mathrm{e}^{0.7435 x}$ & 0.9739 \\
$\mathrm{H}+\mathrm{Al}^{\left(\mathrm{cmol}_{\mathrm{c}} \mathrm{dm}^{-3}\right)}$ & $4.3136 \mathrm{e}^{0.0506 x}$ & 0.7832 \\
$\mathrm{Al}^{3+}\left(\mathrm{cmol}_{\mathrm{c}} \mathrm{dm}^{-3}\right)$ & $0.0707 \mathrm{e}^{0.2633 x}$ & 0.9029 \\
$\mathrm{~K}^{+}\left(\mathrm{cmol}_{\mathrm{c}} \mathrm{dm}^{-3}\right)$ & $0.3639 \mathrm{e}^{0.2187 x}$ & 0.8576 \\
$\mathrm{~V}(\%)$ & $62.913 \mathrm{e}^{-0.034 x}$ & 0.9009 \\
$\mathrm{Al}(\%)$ & $0.8197 \mathrm{e}^{0.3386 x}$ & 0.8273 \\
\hline $\mathrm{R}^{2}$ - Coefficient of determination; Only those adjustments whose coefficient of \\
determination was higher than 0.7 were presented
\end{tabular}

\section{Conclusions}

1. The highest irrigation effluent application applied, namely 200 and $300 \mathrm{~m}^{3} \mathrm{ha}^{-1} \mathrm{~d}^{-1}$, increased $\mathrm{P}$ and $\mathrm{K}$ concentrations in 
the soil. Moreover, there was a relationship between increasing potential acidity and exchangeable acidity with increasing effluent application rate.

2. Concentrations of the studied micronutrients, $\mathrm{Fe}, \mathrm{Cu}$, $\mathrm{Mn}$ and $\mathrm{Zn}$, decreased with time of effluent application for all treatments.

3. The application of treated effluent from poultry slaughterhouse on forest soil, at rates varying from 100 to $300 \mathrm{~m}^{3} \mathrm{ha}^{-1} \mathrm{~d}^{-1}$ for a 15 -month period, caused no significant changes in the values of studied soil attributes when compared to control treatment, except $\mathrm{P}, \mathrm{H}+\mathrm{Al}, \mathrm{Al}^{3+}, \mathrm{K}^{+}$and $\mathrm{V}$.

\section{ACKNowledgments}

We would like to thank Coordenação de Aperfeiçoamento de Pessoal de Nível Superior (CAPES, Brazil) for the financial support, and Cooperativa Lar Agroindustrial, AQUATERRA $_{\text {SOL }}$ research group from the University of Coruña and the Laboratório de Química Ambiental e Instrumental of Universidade Estadual do Oeste do Paraná (UNIOESTE), for the research support.

\section{Literature Cited}

APHA - American Public Health Association. Standard methods for the examination of water and wastewater. 19.ed. Washington: APHA/ AWWA/ WPCF, 1995. 1496p.

Bassaco, M. V. M.; Motta, A. C. V.; Pauletti, V.; Prior, S. A.; Nisgoski, S.; Ferreira, C. F. Nitrogen, phosphorus, and potassium requirements for Eucalyptus urograndis plantations in Southern Brazil. New Forests, v.49, p.681-697, 2018. https://doi.org/10.1007/s11056018-9658-0

Battie-Laclau, P.; Delgado-Rojas, J. S.; Christina, M.; Nouvellon, Y.; Bouillet, J. P.; Piccolo, M. de C.; Moreira, M. Z.; Gonçalves, J. L. de M.; Roupsard, O.; Laclau, J. P. Potassium fertilization increases water-use efficiency for stem biomass production without affecting intrinsic water-use efficiency in Eucalyptus grandis plantations. Forest Ecology and Management, v.364, p.77-89, 2016. https:// doi.org/10.1016/j.foreco.2016.01.004

Bellote, A. F. J.; Ferreira, C. A. Nutrientes minerais e crescimento de árvores adubadas de Eucalyptus grandis, na região do cerrado, no Estado de São Paulo. Boletim Pesquisa Florestal, v.26/27, p.17-65, 1993.

Bustillo-Lecompte, C. F.; Mehrvar, M. Slaughterhouse wastewater characteristics, treatment, and management in the meat processing industry: A review on trends and advances. Journal of Environmental Management, v.161, p.287-302, 2015. https:// doi.org/10.1016/j.jenvman.2015.07.008

Degens, B. P.; Schipper, L. A.; Claydon, J. J.; Russell, J. M.; Yeates, G. W. Irrigation of an allophanic soil with dairy factory effluent for 22 years: Responses of nutrient storage and soil biota. Australian Journal of Soil Research, v.38, p.25-36, 2000. https:// doi.org/10.1071/SR99063

El-Nahhal, Y.; Tubail, K.; Safi, M.; Safi, J. Effect of treated waste water irrigation on plant growth and soil properties in Gaza strip, Palestine. American Journal of Plant Sciences, v.4, p.1736-1743, 2013. https://doi.org/10.4236/ajps.2013.49213
EMBRAPA - Empresa Brasileira de Pesquisa Agropecuária. Manual de métodos de análises de solo. 2.ed. Rio de Janeiro: Embrapa Solos, 1997. 212p.

Fernandes, E. T.; Cairo, P. A. R.; Novaes, A. B. de. Respostas fisiológicas de clones de eucalipto cultivados em casa de vegetação sob deficiência hídrica. Ciência Rural, v.45, p.29-34, 2015. https:// doi.org/10.1590/0103-8478cr20120152

Guo, L. B.; Sims, R. E. H. Effect of meatworks effluent irrigation on soil, tree biomass production and nutrient uptake in Eucalyptus globulus seedlings in growth cabinets. Bioresource Technology, v.72, p.243-251, 2000. https://doi.org/10.1016/S0960-8524(99)00115-7

Guo, L. B.; Sims, R. E. H. Soil response to eucalypt tree planting and meatworks effluent irrigation in a short rotation forest regime in New Zealand. Bioresource Technology, v.87, p.341-347, 2003. https://doi.org/10.1016/S0960-8524(02)00231-6

Hermes, E.; Vilas Boas, A. M. de; Rodrigues, L. N.; Melo, E. L.; Gonçalves, M. P.; Lins, M. A.; Berger, J. S. Process capacity index in drip irrigation with cassava wastewater processing. African Journal of Agricultural Research, v.10, p.1427-1433, 2015. https://doi.org/10.5897/AJAR2015.9610

Jiménez-Cisneros, B. Wastewater reuse to increase soil productivity. Water Science and Technology, v.32, p.173-180, 1995. https:// doi.org/10.2166/wst.1995.0484

Kinraide, T. B. Identity of the rhizotoxic aluminum species. Plant and Soil, v.134, p.167-178, 1991. https://doi.org/10.1007/BF00010729

Kochian, L. V. Cellular mechanisms of aluminum toxicity and resistance in plants. Annual Review of Plant Physiology and Plant Molecular Biology, v.46, p.237-260, 1995. https://doi.org/10.1146/ annurev.pp.46.060195.001321

Laclau, J. P.; Ranger, J.; Gonçalves, J. L. M. de; Maquère, V.; Krusche, A. V.; M’bou, A. T.; Nnouvellon, Y.; Saint-André, L.; Bouillet, J. P.; Piccolo, M. C. de; Deleporte, P. Biogeochemical cycles of nutrients in tropical Eucalyptus plantations: Main features shown by intensive monitoring in Congo and Brazil. Forest Ecology and Management, v.259, p.1771-1785, 2010. https://doi. org/10.1016/j.foreco.2009.06.010

Li, Z.; Shuman, L. M. Heavy metal movement in metal-contamined soil profiles. Soil Science, v.161, p.656-666, 1996. https://doi. org/10.1097/00010694-199610000-00003

Malavolta, E.; Vitti, G. C.; Oliveira, S. A. Avaliação do estado nutricional das plantas: Princípios e aplicações. 2.ed. Piracicaba: Editora Potafos, 1997. 319p.

Maroneze, M. M.; Zepka, L. Q.; Vieira, J. G.; Queiroz, M. I.; JacobLopes, E. A tecnologia de remoção de fósforo: Gerenciamento do elemento em resíduos industriais. Revista Ambiente e Água, v.9, p.445-458, 2014.

Mendes, H. S. J.; Paula, N. F. de; Scarpinatti, E. A.; Paula, R. C. Respostas fisiológicas de genótipos de Eucalyptus grandis x E. urophylla à disponibilidade hídrica e adubação potássica. Cerne, v.19, p.603611, 2013. https://doi.org/10.1590/S0104-77602013000400010

Minhas, P. S.; Yadav, R. K.; Lal, K.; Chaturvedi, R. K. Effect of long-term irrigation with wastewater on growth, biomass production and water use by eucalyptus (Eucalyptus tereticornis Sm.) planted at variable stocking density. Agricultural Water Management, v.152, p.151-160, 2015. https://doi.org/10.1016/j.agwat.2015.01.009

Morais, J. Uniformidade de irrigação por gotejamento usando efluente tratado de abatedouro de aves. Cascavel: UNIOESTE, 2017. 87p. Dissertação Mestrado 
Nascimento, C. W. A.; Fontes, R. L. F.; Neves, L. C. L.; Melicio, A. C. F. D. Fracionamento, dessorção e extração química de zinco em Latossolos. Revista Brasileira de Ciência do Solo, v.26, p.599-606, 2002. https://doi.org/10.1590/S0100-06832002000300004

Silveira, R. L. V. A.; Gava, J. L. Nutrição e adubação fosfatada em eucalipto. In: Yamada, T.; Abdalla, S. R. S. Fósforo na agricultura brasileira. Piracicaba: Editora Potafos, 2004. Cap.19, p.495-536.

Stahl, R. S.; James, B. R. Zinc sorption by manganese-oxide-coated sand as a function of $\mathrm{pH}$. Soil Science Society of America Journal, v.55, p.1291-1294, 1991. https://doi.org/10.2136/ sssaj1991.03615995005500050016x
Tahara, K.; Norisada, M.; Hogetsu, T.; Kojima, K. Aluminum tolerance and aluminum-induced deposition of callose and lignin in the root tips of Melaleuca and Eucalyptus species. Journal of Forest Research, v.10, p.325-333, 2005. https://doi.org/10.1007/s10310-005-0153-z

Tzanakakis, V. A.; Paranychianakis, N. V.; Londra, P. A.; Angelakis, A. N. Effluent application to the land: Changes in soil properties and treatment potential. Ecological Engineering, v.37, p.1757-1764, 2011. https://doi.org/10.1016/j.ecoleng.2011.06.024

USDA - United States Department of Agriculture. Production supply and distribution. Available on: <https://apps.fas.usda.gov/ psdonline/app/index.html\#/app/adv>. Accessed on: Mar. 2018. 